\title{
Aortic homografts: Unrealized expectations and hard reoperations at the end
}

\author{
Juan A. Crestanello, MD
}

\author{
From the Department of Cardiovascular Surgery, Mayo Clinic, Rochester, Minn. \\ Disclosures: Author has nothing to disclose with regard to commercial support. \\ Received for publication April 21, 2018; accepted for publication April 23, 2018; available ahead of print June 5, \\ 2018. \\ Address for reprints: Juan A. Crestanello, MD, Department of Cardiovascular Surgery, Mayo Clinic, 200 First St \\ SW, Rochester, MN 55905 (E-mail: crestanello.juan@mayo.edu). \\ J Thorac Cardiovasc Surg 2018;156:1351-2 \\ $0022-5223 / \$ 36.00$ \\ Copyright (C) 2018 by The American Association for Thoracic Surgery \\ https://doi.org/10.1016/j.jtcvs.2018.04.099
}

Cryopreserved aortic homografts have been considered an ideal alternative for aortic root replacement in young patients. Superior hemodynamics, resistance to infection, available extra tissue to reconstruct the root, avoidance of anticoagulation, and long-term durability are some of the advantages claimed by their advocates. Fifty-three years after their introduction by O'Brien and colleagues, ${ }^{1}$ however, most of those claims have not been realized. In addition, the availability of homografts and the inherent challenges associated with their implantation and reoperation have limited their widespread use.

In this issue of the Journal, Nappi and colleagues ${ }^{2}$ reported the experience of 4 surgeons, spanning 17 years, with 210 young patients who underwent aortic root replacement with cryopreserved aortic allografts. The findings of this report exemplify (1) the "unrealized expectations," as the outcomes were at least similar to if not worse than those of replacement with biologic or mechanical valves, and (2) the "hard reality" of a difficult reoperation when the homograft deteriorates.

First, root replacement with a homograft is a technically demanding operation performed only a few times a year even by "experienced" surgeons. Nappi and colleagues ${ }^{2}$ performed on average fewer than 4 procedures per surgeon per year during the study period. The high operative mortality $(5.7 \%)$ and the prolonged crossclamp and bypass times (in excess of 3 and 4 hours, respectively) reflect the complexities and technical difficulties of these operations.

Second, the key of successful endocarditis treatment is radical débridement of all infected tissue. ${ }^{3}$ Although in the report of Nappi and colleagues ${ }^{2}$ there was no early recurrence of endocarditis, and the freedom from late endocarditis was $98 \%$, there is no conclusive evidence to sustain the contention that allograft tissue is more resistant to infection, or that in endocarditis it is associated with improved cure rate, lower recurrence rate, or improved survival relative to mechanical or biologic valves or to conduits. ${ }^{4-6}$

Third, superior hemodynamics and avoidance of anticoagulation are the only 2 of those promises that have been

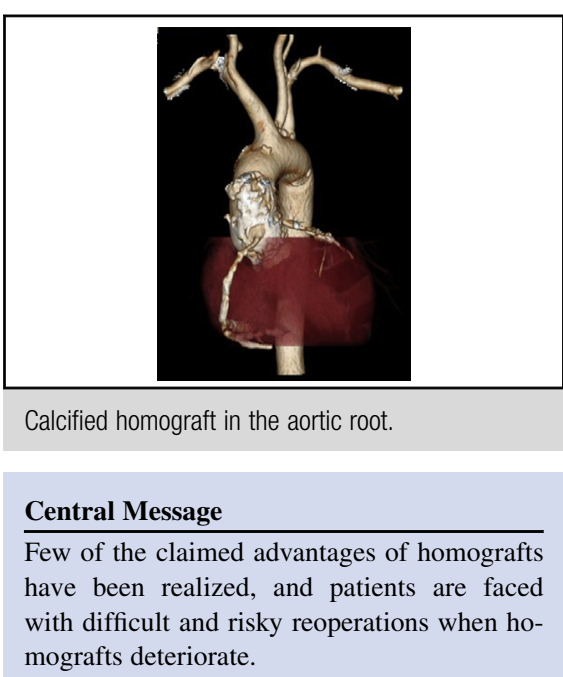

See Article page 1357.

realized. Lower gradients are observed in allografts than in mechanical or biologic prostheses. ${ }^{7}$ The clinical significance of these findings is unclear, however, because it is unknown whether they result in improved survival, reverse remodeling or symptoms. Avoidance of anticoagulation is particularly advantageous for women of childbearing age because it simplifies their management during pregnancy.

Fourth, because these patients are young, the likelihood of reoperation is very high. Structural valve deterioration, endocarditis, and technical failures are the most common reasons for reoperation. Structural valve deterioration usually presents as valve regurgitation in the second decade after implantation. This increased rate of reoperation in the second decade after implantation is consistently and predictably observed in all the published series, ${ }^{8}$ as it is in this current report of Nappi and colleagues. ${ }^{2}$ Similarly, in this current report of Nappi and colleagues, ${ }^{2}$ freedom from reoperation decreased from $84 \%$ at 15 years to $15 \%$ at 20 years. These rates of reoperation are hard to differentiate from the reported rates of reoperation of biologic valves and are clearly higher than the rates for mechanical valves. $7,9,10$

Finally, once the homograft fails, the patient and the surgeon face the hard reality of a technically difficult and risky reoperation. Reoperations in patients with calcified homograft wall, leaflets, and coronary artery buttons require aggressive débridement, coronary mobilization and in many cases a redo root replacement (Figure 1). These 


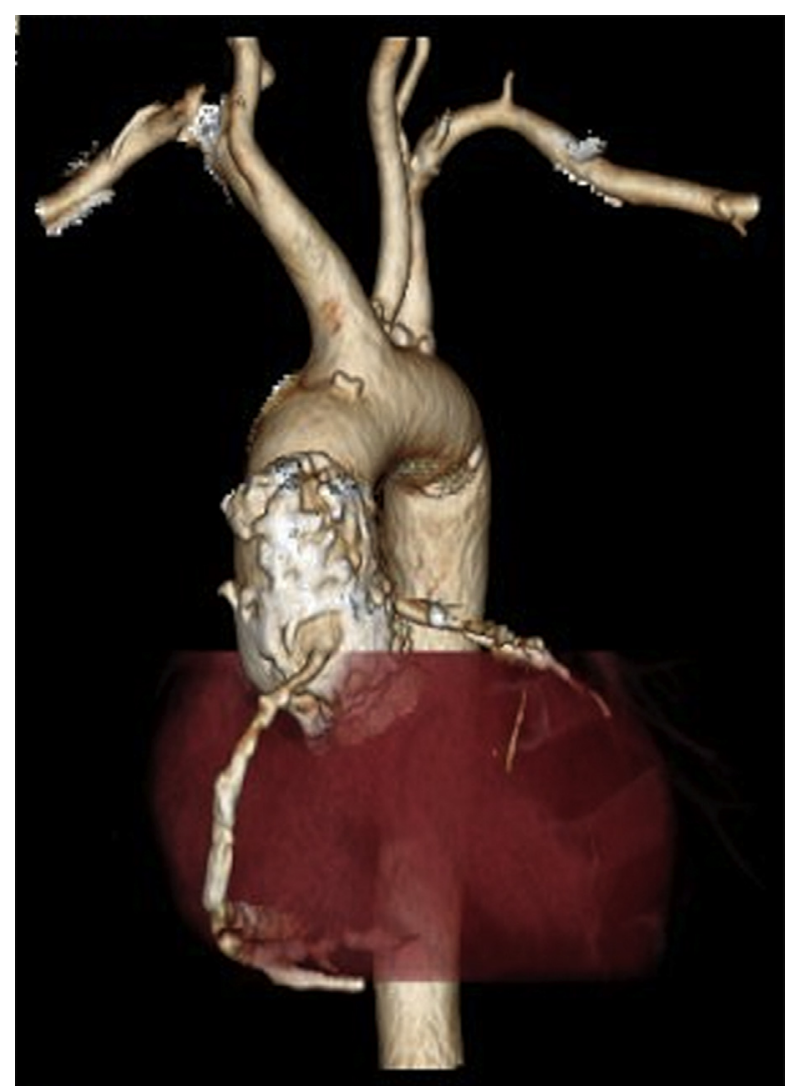

FIGURE 1. Calcified homograft in the aortic root.

procedures are associated with operative mortality of $2 \%$ to $18 \%,{ }^{8,11}$ which is higher than the risk of reoperation after aortic valve replacement with mechanical or biologic valves. ${ }^{9,12}$ Although transcatheter aortic valve replacement may be a less risky approach in the absence of infection, long-term results have not been reported.

Let us conclude with the recognition that aortic homografts have a role in selected patients requiring root replacements, particularly young women requiring extensive root reconstruction. The benefits of aortic homografts relative to bioprostheses and mechanical valves are limited and need to be weighed against the unavoidable and significant risk of reoperation.

\section{References}

1. O'Brien MF, Stafford EG, Gardner MA, Pohlner PG, McGiffin DC. A comparison of aortic valve replacement with viable cryopreserved and fresh allograft valves, with a note on chromosomal studies. J Thorac Cardiovasc Surg. 1987; 94:812-23.

2. Nappi F, Nenna A, Petitti T, Spadaccio C, Gambardella I, Lusini M, et al. Long-term outcome of cryopreserved allograft for aortic valve replacement. J Thorac Cardiovasc Surg. 2018;156:1357-65.

3. David TE, Gavra G, Feindel CM, Regesta T, Armstrong S, Maganti MD. Surgical treatment of active infective endocarditis: a continued challenge. J Thorac Cardiovasc Surg. 2007; 133:144-9.

4. Jassar AS, Bavaria JE, Szeto WY, Moeller PJ, Maniaci J, Milewski RK, et al. Graft selection for aortic root replacement in complex active endocarditis: does it matter? Ann Thorac Surg. 2012;93:480-7.

5. Kim JB, Ejiofor JI, Yammine M, Camuso JM, Walsh CW, Ando M, et al. Are homografts superior to conventional prosthetic valves in the setting of infective endocarditis involving the aortic valve? J Thorac Cardiovasc Surg. 2016;151: 1239-46. 1248.e1-2

6. Avierinos JF, Thuny F, Chalvignac V, Giorgi R, Tafanelli L, Casalta JP, et al. Surgical treatment of active aortic endocarditis: homografts are not the cornerstone of outcome. Ann Thorac Surg. 2007;84:1935-42.

7. Svensson LG, Pillai ST, Rajeswaran J, Desai MY, Griffin B, Grimm R, et al. Long-term survival, valve durability, and reoperation for 4 aortic root procedures combined with ascending aorta replacement. J Thorac Cardiovasc Surg. 2016; 151:764-74.e4

8. Bekkers JA, Klieverik LM, Raap GB, Takkenberg JJ, Bogers AJ. Re-operations for aortic allograft root failure: experience from a 21-year single-center prospective follow-up study. Eur J Cardiothorac Surg. 2011;40:35-42.

9. Chiang YP, Chikwe J, Moskowitz AJ, Itagaki S, Adams DH, Egorova NN Survival and long-term outcomes following bioprosthetic vs mechanical aortic valve replacement in patients aged 50 to 69 years. JAMA. 2014;312: 1323-9.

10. Smedira NG, Blackstone EH, Roselli EE, Laffey CC, Cosgrove DM. Are allografts the biologic valve of choice for aortic valve replacement in nonelderly patients? Comparison of explantation for structural valve deterioration of allograft and pericardial prostheses. J Thorac Cardiovasc Surg. 2006;131:558-64.e4.

11. Nowicki ER, Pettersson GB, Smedira NG, Roselli EE, Blackstone EH, Lytle BW. Aortic allograft valve reoperation: surgical challenges and patient risks. Ann Thorac Surg. 2008;86:761-8.e2.

12. Kaneko T, Vassileva CM, Englum B, Kim S, Yammine M, Brennan M, et al. Contemporary outcomes of repeat aortic valve replacement: a benchmark for transcatheter valve-in-valve procedures. Ann Thorac Surg. 2015;100:1298-304; discussion 1304. 